\title{
Early selection of parents and trees in Eucalyptus full-sib progeny tests
}

\author{
José Luis Lima ${ }^{1 *}$, João Cândido de Souza ${ }^{2}$, Magno Antônio Patto Ramalho ${ }^{2}$, Hélder Bolognani Andrade ${ }^{1}$ and Leonardo Chagas de
} Sousa ${ }^{1}$

Received 14 January 2010

Accepted 17 April 2010

ABSTRACT - This study aimed to evaluate the efficiency of early selection for parents and trees for cloning in full-sib progeny tests of Eucalyptus spp. The 61 hybrid progenies were evaluated in the north, northwest and central state of Minas Gerais, Brazil, in a randomized complete block design with three replications, in 2001. The trait circumference at breast height (CBH) was evaluated 30 and 84 months after planting in five-plant rows. The selection efficiency was assessed by the fluctuation of genetic and phenotypic parameters, coincidence index, genetic correlation, phenotypic correlation, Spearman rank correlation, correlated response, gain per year and repeatability of phenotypic values at the plant level. All methodologies indicated that early selection is effective both in the selection of parents and the selection of trees for cloning.

Key words: coincidence index, genetic correlation, correlated response, gain per year.

\section{INTRODUCTION}

One of the main economic activities in Minas Gerais state is the steel industry, which consumes large quantities of charcoal. This raw material is produced mainly in the north and northwestern regions of the state, where severe droughts occur. This climatic condition makes it difficult to obtain eucalyptus high-yielding clones. However, with specific improvement programs for these areas significant results have been obtained for the crop.

The first strategy used in the breeding programs was the introduction and identification of potential species. Results indicated that the species E. camaldulensis, $E$. urophylla, E. cloeziana, E. terenticornis, E. pellita and Corimbia citriodora were the most promising (Andrade et al. 1994). After the initial work, efforts were directed towards the mass selection of superior plants and selection with half-sib families, leading to an improvement of the species as well as better seed quality for commercial plantations. Until the late 1990s, forest plantations in these regions had been grown from seeds, resulting in a high heterogeneity of the stands. As clonal propagation became available, the entire forestry sector turned to clonal plantations, increasing the gains with the use of this technique even more (Gonçalves et al. 2001).

The possibility of maintaining all of the genetic variance caused an adjustment in the strategies of improvement programs. The programs were directed towards obtaining interspecific hybrids. By this strategy, traits found in different species can be associated, heterosis exploited and more stable clones obtained in conditions considered marginal for the cultivation of the

\footnotetext{
${ }^{1}$ Vallourec \& Mannesmann Florestal, Rua Honduras, 78, 35.7790-000, Curvelo, MG, Brazil. ${ }^{*}$ E-mail: joseluis_li@yahoo.com.br

${ }^{2}$ Universidade Federal de Lavras (UFLA), C.P. 3037, 37.200-000, Lavras, MG, Brazil
} 
species per se (Bouvet et al. 2009). This procedure did not only provide yield increases, but also paved the way to a more homogenous final product (charcoal).

However, it should be noted that cloning is a "dead end" technique, in other words, the maximum gain is obtained in a single generation and thereafter, no additional gain is achieved. Therefore, to ensure the development of clones with better performance than the existing, it is important that recurrent selection programs should be carried out in addition to clonal selection (Gonçalves et al. 2001, Bison et al. 2006). However, the effectiveness of this strategy depends on the interval between generations.

In this context, the use of early selection makes recurrent selection programs feasible and concomitantly achieves higher gains per unit time. The efficiency of this procedure has been documented elsewhere (Marques Júnior et al. 1996, Pereira et al. 1997, Rezende et al. 1994). However, half-sib progenies were evaluated in these studies, which did not allow a comprehensive understanding of the behavior of the total genetic variance over the course of time, because the genetic variance among progeny consists of additive variance only. The assessment of full-sib progenies however detected, aside from the additive component, genetic dominance variance (Falconer and Mackay 1996).

According to Bouvet et al. (2009), alterations in the additive and dominance effects throughout the eucalyptus tree development have been little studied. This information underlies the choice of the best time to conduct the selection and thereby maximizes the expected gains. In the above study, the authors found that the ratio of additive genetic variance and total genetic variance tended to decrease with time and the broad-sense heritability increased slightly for the traits tree height (35-50\%) and circumference at breast height (20-40\%). It follows, therefore, that dominance variance increases at a greater rate than additive variance and that the best age to select trees in hybrid progeny tests would be seven years.

In this context, this study aimed to evaluate the efficiency of early selection in progeny trials of Eucalyptus hybrid, both in the selection of parents as well as the selection of trees for cloning.

\section{MATERIALAND METHODS}

\section{Experimental setup}

The study was conducted in an area of the company at V \& M Florestal. By controlled crosses involving the species Eucalyptus urophylla, E. camaldulensis, E. grandis and E. pellita 61 full-sib progenies were obtained. These hybrid progenies along with three controls were planted in 2001, in three different regions of the company with contrasting soil and climatic characteristics, in the north, northwest and central state of Minas Gerais, in the municipalities of Bocaiúva, João Pinheiro and Paraopeba respectively. The experiment was arranged in a randomized complete block design with three replications; the plots consisted of rows of five plants, spaced $3 \times 3 \mathrm{~m}$. The silvicultural managements were the same as used in the commercial plantations. The trait under study was circumference at breast height $(\mathrm{CBH})$, measured twice: 30 months and 84 months after planting.

\section{Parent selection}

The data obtained in the evaluation of full-sib progenies were analyzed at the plant level and in combined analysis of variance according to the procedures described by Ramalho et al. (2005). The analyses were performed using PROC GLM (Procedure for General Linear Models) of SAS (SAS Institute 2000). Based on the decomposition of the expected mean squares, genetic and phenotypic parameters over the course of time. The upper and lower limits of heritability were calculated using the expression presented by Knapp et al. (1985), at a reliability coefficient of $95 \%$.

The efficiency of early selection in the choice of the best progenies was evaluated by six different methodologies: fluctuations in genetic and phenotypic parameters over the course of time; coincidence index of the progenies selected after 30 and after 84 months, using the expression of Hamblin and Zimmermann (1986); genetic correlation $\left(\hat{r}_{g}\right)$ (Ramalho et al. 2005); Spearman rank correlation $(\hat{\rho})$ (Steel and Torrie 1988); correlated response to selection and, finally, expected gains per year.

\section{Selection of trees for cloning}

The efficiency of early selection of the best trees for cloning was assessed by the same methodologies described in the above item. Beside these, the phenotypic correlation $\left(\hat{r}_{f}\right)\left(\right.$ Ramalho et al. 2005) and repeatability $\left(\hat{\rho}_{\delta}\right)$ of the phenotypic values were estimated at the plant level, according to Resende (2002). The variability for selection of the best trees was also evaluated by the distribution of predicted genotypic values $(\mu+g)$ at the plant level, obtained in the plant analysis by the mixed models REML/BLUP, using the software Selegen (Resende 2007). 


\section{RESULTS AND DISCUSSION}

Two targets were set regarding the use of early selection that will be presented in this section: identification of the best progenies to establish of a bank of elite matrices and identification of the best trees for cloning.

\section{Progeny selection}

Since the correlation between $\mathrm{CBH}$, height and volume is usually high (Paula et al. 2002, Pereira et al. 1997, Tolfo et al. 2005), the study trait is CBH. Sources of variation in progenies obtained in the combined analysis of variance were always significant $(\mathrm{P}<0.01)$ (Table 1$)$. The estimated genetic and phenotypic parameters show that there is sufficient genetic variability to predict selection gains.

Table 1. Summary of combined analyses of variance of locations, of data obtained in the full-sib progeny tests of Eucalyptus spp., after 30 and 84 months, and estimates of genetic and phenotypic parameters for circumference at breast height $(\mathrm{CBH})$ in $\mathrm{cm}$

\begin{tabular}{|c|c|c|c|c|}
\hline \multirow{2}{*}{ Sources of variation } & \multicolumn{2}{|c|}{30 months } & \multicolumn{2}{|c|}{84 months } \\
\hline & df & MS & df & MS \\
\hline Replications/Locations & 6 & 12.9 & 6 & 49.2 \\
\hline Progenies $(\mathrm{P})$ & 60 & $71.2^{* *}$ & 60 & $337.9^{* *}$ \\
\hline Locations (L) & 2 & $3889.9^{* *}$ & 2 & $6252.9^{* *}$ \\
\hline $\mathrm{P} \times \mathrm{L}$ & 120 & $16.1^{* *}$ & 120 & $68.6^{* *}$ \\
\hline Error & 353 & 11.3 & 360 & 42.1 \\
\hline Total & 541 & & 548 & \\
\hline $\mathrm{CV}_{\mathrm{e}}(\%)$ & & 12.6 & & 15.9 \\
\hline $\mathrm{CV}_{\mathrm{g}}(\%)$ & & 9.2 & & 13.4 \\
\hline$\hat{\sigma}_{p}^{2}$ & & 6.12 & & 29.91 \\
\hline$\hat{\sigma}_{f}^{2}$ & & 7.91 & & 37.54 \\
\hline$\hat{\sigma}_{p l}^{2}$ & & 1.57 & & 8.8 \\
\hline$\hat{\sigma}_{p l}^{2} / \hat{\sigma}_{p}^{2}(\mathrm{x} 100)$ & & 25.6 & & 29.5 \\
\hline$\hat{h}_{a}^{2}$ & (64 & $\begin{array}{l}77.4 \\
3-85.3)\end{array}$ & $(67$ & $\begin{array}{c}79.7 \\
9-86.8)\end{array}$ \\
\hline Mean & & 26.8 & & 40.6 \\
\hline
\end{tabular}

CVe (\%): coefficient of experimental variation; $\mathrm{CVg}(\%)$ : coefficient of genetic variation; $\hat{\sigma}_{p}^{2}$ : genetic variance among progenies $; \hat{\sigma}_{f}^{2}:$ phenotypic variance; $\hat{\sigma}_{p l}^{2}$; variance of the interaction progeny x location; $\hat{h}_{a}^{2}$ : broadsense heritability at the level of progeny means.

It was observed that the estimates of genetic variance among progenies $\left(\hat{\sigma}_{p}^{2}\right)$ increased over the course of time. It could be argued that the $\hat{\sigma}_{p}^{2}$ estimate increased due to tree growth. Interestingly the same trend, though weaker, was observed in the estimation of genetic coefficients of variation $(\mathrm{CVg})$. Thus, the genetic variance tended to increase proportionally to the trait mean at the different ages.

However, estimates of heritability $\left(\hat{h}_{a}^{2}\right)$ for the selection of the progeny mean were similar at both ages (Table 1). Furthermore, note that the confidence intervals of these $\hat{h}_{a}^{2}$ estimates overlap. Thus, it may be concluded that the estimates at different ages were similar. Since in the selection of any trait the $\hat{h}^{2}$ estimate is primarily responsible for the gain expected with selection (Falconer and Mackay 1996), these results suggest that the early selection of progenies is efficient. Similar results were obtained by Lambeth (1980), Marques Jr. et al. (1996) and Pereira et al. (1997).

Estimates of $\hat{h}^{2}$ available in the literature, mainly in studies conducted in the region, are not directly comparable to those obtained in this study, because it is related to the evaluation of half-sibs (Marques Júnior et al. 1996, Pereira et al. 1997). In this type of progeny, $1 / 4$ of the additive variance among families is explored. In the case of fullsibs, as used in this study, $\hat{\sigma}_{p}^{2}$ consists of $1 / 2$ of the additive variance $\left(\sigma_{A}^{2}\right)$ plus $1 / 4$ of the dominance variance $\left(\sigma_{D}^{2}\right)$. There is still no consensus on the contribution of $\sigma_{D}^{2}$ to genetic variance, since the actual contribution of dominance effects to the expression of $\mathrm{CBH}$ is uncertain. In a study of Bouvet et al. (2009), there is evidence that $\sigma_{D}^{2}$ is significant for growth-related traits. However, the study of Bison et al. (2004) shows dominance in the genetic control of these traits, but not high.

It is noteworthy that the progeny $\mathrm{x}$ location interaction was significant in both evaluations (Table 1), but the proportions of the variances of progeny $x$ location interaction $\left(\hat{\sigma}_{p l}^{2}\right)$ on $\hat{\sigma}_{p}^{2}$ were less than $29.5 \%$, indicating that despite the influence of interaction on the progeny performance, it was of small magnitude. The selection of the best progenies should therefore be based on the average of analysis of variance of locations. Similar results were obtained in other studies conducted in regions close to the present study (Andrade et al. 1994, Marques Júnior et al. 1996, Pereira et al. 1997).

It is worth mentioning that the efficiency of any forest breeding program will be the greater, the earlier the selection is made (Kerr et al. 2004, Pereira et al. 1997). To evaluate the efficiency of this strategy in full-sib progenies the 10 (control) best and 10 worst progeny were selected 30 and 84 months after planting. The results indicate a high degree of coincidence between the progenies selected in the two age groups $(66.21 \%)$. Of the 10 progenies selected after 30 
months, seven were selected again after 84 months. The efficiency of early selection was also evidenced by the high-magnitude estimate of genetic correlation $\left(\hat{r}_{g}\right)$ and Spearman rank correlation ( $\hat{\rho}$ ), with values of 0.98 and 0.91 , respectively.

Although the ranking of progenies selected after 30 months was not largely different from that after 84 months, the question arises whether the average of seven-yearold trees selected at the age of 30 months is lower than the average of tree selected at the age of seven years. The mean of the progenies selected after 84 months was 1.37 $\%$ higher than after 30 months; this difference does not justify waiting with selection for seven years. This confirmed once again the efficiency of early selection.

For a better comparison of the selection periods, gains should be estimated annually. Based on the results, it was shown that the number of years until beginning selection has a great influence on the expected gains in Eucalyptus breeding programs and that results are best in the case of early selection. In this context, the gain with selection after 30 months was $112 \%$ greater than what would be obtained with selection after 84 months. Similar results were reported by Borralho et al. (1992) and Pereira et al. (1997). Aside from higher gains per year with early selection, this strategy lets breeding programs become much more dynamic, allowing the recombination of the best parents within a shorter period.

The feasibility of early selection of potential progenies and trees in Eucalyptus shows a glimpse of the possibility of practicing recurrent selection with greater dynamism. Some authors have commented that reciprocal recurrent selection is efficient in the improvement of eucalyptus. However, with a view to charcoal production, the best strategy seems to be the establishment of synthetic populations that are subjected to successive cycles of intrapopulation recurrent selection. Kerr et al. (2004) called this procedure intrapopulation recurrent selection in synthetic populations (IRSSP).

According to these authors, IRSSP is associated with higher genetic gains per year, because the generation interval is lower. Moreover, it has the advantages: association of traits found in distinct species; exploitation of technical wood properties which are controlled mainly by additive gene effects; and maintenance of the existing heterosis in the plants used in crosses (Kerr et al. 2004).

Although IRSSP is similar to intrapopulation recurrent selection, it should not be conducted in the same manner. According to Kerr et al. (2004), IRSSP should be driven more dynamically; in each selection cycle new parents may be included, clones or promising progenies can be found in hybrid tests, among other genotypes. Parents that do not perform well in the progeny tests may also be removed while simultaneously selecting the best trees for cloning.

The assessment of the potential of different species in the combined analysis of variance showed highest means of the hybrids involving E. camaldulensis with $E$. urophylla and E. grandis. Despite the high potential observed in hybrids of E. camaldulensis x E. urophylla to be exploited in the test regions, only 5 of the 43 progenies evaluated were selected, i.e., $11.62 \%$. Of the 15 evaluated progenies of E. camaldulensis x E. grandis hybrids, five were among the selected ten, resulting in a greater proportion of selected progenies $(33.33 \%)$ of this cross. However, these progenies should be evaluated for basic wood density, since it is known that the basic wood density of the species E. grandis is low, which is undesirable for charcoal production.

\section{Selection of trees for cloning}

The selection accuracy of plant analysis exceeded $77.81 \%$ (Tables 2, 3 and 4). These estimates indicate a high to very high experimental accuracy (Resende and Duarte 2007). The source of progeny variation was significant $(\mathrm{P}<0.01)$ in all analyses and the estimates of genetic and phenotypic parameters evidenced the possibility of gains with selection.

Table 2. Summary of analyses of variance and plant estimates of genetic and phenotypic parameters for $\mathrm{CBH}(\mathrm{cm})$, of data obtained in the evaluation of full-sib progeny tests of Eucalyptus spp. in Bocaiuva, at the age of 30 and 84 months

\begin{tabular}{|c|c|c|c|c|}
\hline \multirow{2}{*}{ Sources of variation } & \multicolumn{2}{|c|}{30 months } & \multicolumn{2}{|c|}{84 months } \\
\hline & df & MS & df & MS \\
\hline Replications & 2 & 1.7 & 2 & 21.3 \\
\hline Progenies & 60 & $71.4 * *$ & 60 & $370.9 * *$ \\
\hline Error & 120 & 28.9 & 120 & 84.1 \\
\hline Mean variation within plots & 660 & 19.5 & 593 & 76.3 \\
\hline Total & 842 & & 775 & \\
\hline Accuracy (\%) & & 77.8 & & 89.8 \\
\hline$\hat{\sigma}_{p}^{2}$ & & 3.2 & & 24.3 \\
\hline$\hat{\sigma}_{f}^{2}$ & & 5.3 & & 31.4 \\
\hline$\hat{h}_{i}^{2}$ & & $\begin{array}{c}24.5 \\
(17.7-31.3)\end{array}$ & & $\begin{array}{c}45.9 \\
(36.2-55.6)\end{array}$ \\
\hline Mean & & 21.8 & & 33.9 \\
\hline
\end{tabular}


Table 3. Summary of analyses of variance and plant estimates of genetic and phenotypic parameters for $\mathrm{CBH}(\mathrm{cm})$, of data obtained in the evaluation of full-sib progeny tests of Eucalyptus spp. in Paraopeba, at the age of 30 and 84 months

\begin{tabular}{|c|c|c|c|c|}
\hline \multirow{2}{*}{ Sources of variation } & \multicolumn{2}{|c|}{30 months } & \multicolumn{2}{|c|}{84 months } \\
\hline & df & MS & df & MS \\
\hline Replications & 2 & 133.8 & 2 & 471.1 \\
\hline Progenies & 60 & $177.9 * *$ & 60 & $776.2 * *$ \\
\hline Error & 120 & 52.1 & 120 & 200.9 \\
\hline Mean variation within plots & 645 & 43.6 & 534 & 217.8 \\
\hline Total & 827 & & 716 & \\
\hline Accuracy (\%) & & 85.5 & & 87.9 \\
\hline$\hat{\sigma}_{p}^{2}$ & & 9.7 & & 55.6 \\
\hline$\hat{\sigma}_{f}^{2}$ & & 13.8 & & 75.5 \\
\hline$\hat{h}^{2}$ & & 34.4 & & 37.7 \\
\hline$h_{i}^{-}$ & & $(26.2-42.5)$ & & $(28.6-46.9)$ \\
\hline Mean & & 27.5 & & 43.6 \\
\hline
\end{tabular}

The variability in $\mathrm{CBH}$ can also be verified by the frequency distributions of the estimates of predicted genotypic values $(\mu+g)$. The amplitudes of variation were largest 84 months after planting, which was due to the accelerated growth of certain genotypes, which stood out among the others (Andrade et al. 2006). In João Pinheiro, $6.49 \%$ of the trees evaluated after 30 months performed better than the most commonly used clone in the company, while after 84 months, this percentage was $3.43 \%$. At the other two sites, this value was lower. It should be noted that the number of plants evaluated per progeny and the mean of most of them was low, resulting in a lower number of plants performing better than the control. However, if other relevant traits of charcoal production were taken into consideration, clones with benefits that exceed the pre-existing could certainly be identified.

It was found that at all locations, the $\hat{\sigma}_{p}^{2}$ estimates increased over the course of time. The same trend was observed for phenotypic variance $\left(\sigma_{f}^{2}\right)$, so that the broadsense heritability at the level of progeny mean remained constant over time, except in Bocaiúva (Table 2). Similar results were found in other studies (Rezende et al. 1994, Pereira et al. 1997).

Heritability for selection at the plant level $\left(\hat{h}_{i}^{2}\right)$ varied among sites. In Bocaiúva, $\hat{h}_{i}^{2}$ was higher after 84 than after 30 months (Table 2). At the other two sites, the confidence interval overlaps, allowing the conclusion that the evaluation age did not influence the $\hat{h}_{i}^{2}$ estimate (Tables 3 and 4). Although there is dominance in the estimation of
Table 4. Summary of analyses of variance and plant estimates of genetic and phenotypic parameters for $\mathrm{CBH}(\mathrm{cm})$, of data obtained in the evaluation of full-sib progeny tests of Eucalyptus spp. in João Pinheiro, at the age of 30 and 84 months

\begin{tabular}{|c|c|c|c|c|}
\hline \multirow{2}{*}{ Sources of variation } & \multicolumn{2}{|c|}{30 months } & \multicolumn{2}{|r|}{84 months } \\
\hline & df & MS & df & MS \\
\hline Replications & 2 & 27.8 & 2 & 16.0 \\
\hline Progenies & 60 & $201.8^{* *}$ & 60 & $614.8 * *$ \\
\hline Error & 113 & 55.8 & 120 & 167.9 \\
\hline Mean variation within plots & 579 & 42.8 & 544 & 167.4 \\
\hline Total & 754 & & 726 & \\
\hline Accuracy (\%) & & 87.2 & & 87.2 \\
\hline$\hat{\sigma}_{p}^{2}$ & & 11.9 & & 43.7 \\
\hline$\hat{\sigma}_{f}^{2}$ & & 16.5 & & 60.0 \\
\hline$\hat{h}_{i}^{2}$ & & $\begin{array}{c}40.5 \\
(31.3-49.7)\end{array}$ & & $\begin{array}{c}35.9 \\
(27.0-44.8)\end{array}$ \\
\hline Mean & & 31.1 & & 44.6 \\
\hline
\end{tabular}

genetic variance among plants, this estimate is useful in the selection, since the goal is the establishment of clones. In this case, all genetic variance is exploited in the selection.

The estimates of phenotypic correlations for the different locations exceeded 0.85 , indicating a good association between the tree performance at an early age and the harvest age (seven years). The estimates of Spearman rank correlation $(\hat{\rho})$ were high $(>0.83)$, indicating that the tree ranking was not significantly changed from one evaluation period to another. The coincidence index was also of high, with values $>60.51 \%$.

The selection efficiency was also confirmed by the plant repeatability coefficient $\left(\hat{\rho}_{\delta}\right)$, with estimates of $>0.78$. According to Resende (2002), repeatability coefficients above $80 \%$ are adequate and indicate that, although the ranking of the trees can change from one period to the next, the group of the best should not be changed significantly. This means that selection in only one evaluation period is sufficient - in this case, after 30 months.

Other important evidence in favor of early selection in this study was the performance of 84-month-old plants that had been selected at the age of 30 months (Table 5). Although the predicted genotypic values $(\mu+g)$ are higher in the selection at harvest age ( 84 months), this advantage does not justify waiting for seven years for selection, since the best plants are also included in the selection after 30 months.

Comparing both selection strategies, it was found at all locations that the gains per year were highest with 
Table 5. Response of the 100 best trees identified in tests of 84-month-old full-sib progenies of Eucalyptus spp. by the selection performed after 30 and after 84 months based on the predicted genotypic values $(m+g)$ and estimates of gains per year for circumference at breast height $(\mathrm{cm})$ at three locations

\begin{tabular}{|c|c|c|c|c|c|c|c|}
\hline & \multirow{2}{*}{ Year } & \multicolumn{2}{|c|}{ Bocaiúva } & \multicolumn{2}{|c|}{ Paraopeba } & \multicolumn{2}{|c|}{ João Pinheiro } \\
\hline & & $\mu+g$ & Gain/year (\%) & $\mu+g$ & Gain/year (\%) & $\mu+g$ & Gain/year (\%) \\
\hline $30 / 84$ & 2.5 & 41.46 & 5.49 & 48.88 & 7.86 & 52.84 & 7.95 \\
\hline $84 / 84$ & 7 & 43.8 & 4.18 & 57.23 & 4.45 & 55.26 & 3.40 \\
\hline
\end{tabular}

selection after 30 months (Table 5). The gains were $31 \%$ higher than what would be obtained with selection after 84 months, aside from the fact that the program is much more dynamic with the development of superior clones in a shorter time.

Thus, all methods applied confirmed that the best strategy is to perform early selection of potential trees for cloning and evaluate them thereafter in clonal tests. However, in the selection of trees in the hybrid progeny tests, the selection intensity should not be high, especially at early stages. If a high selection intensity is used, not all plants that would be selected after 30 months would be in the selection after 84 months and the genetic correlation between the performance of the trees selected in the progeny tests and of the same trees in the clonal tests is low.

It could be argued that the best trees were found in the best-performing progenies. It was confirmed that the greatest number of plants was selected from progeny 18 , which had the best mean performance at the three locations. This progeny is derived from a cross of a progeny of $E$. camaldulensis (identified as the matrix of E. camaldulensis number 18) with E. urophylla (identified as the matrix of $E$. urophylla of number 7). A large number of plants of hybrids of E. camaldulensis x E. grandis were also selected, mainly in the region of João Pinheiro. On the other hand, hybrids of E. camaldulensis with E. pellita did not produce trees with satisfactory growth.

\section{ACKNOWLEDGEMENTS}

The authors thank to Coordenação de Aperfeiçoamento de Pessoal de Nível Superior (CAPES) and the Conselho Nacional de Desenvolvimento Científico e Tecnológico $(\mathrm{CNPq})$ for the research fellowships and for financial support.

\title{
Seleção precoce de genitores e árvores em testes de progênies de irmãos completos de Eucalyptus
}

\begin{abstract}
RESUMO - Este trabalho objetivou avaliar a eficiência da seleção precoce de genitores e árvores para clonagem em testes de progênies de irmãos completos de Eucalyptus spp. Foram avaliadas 61 progênies híbridas, na região norte, noroeste e central do estado de Minas Gerais. Os experimentos foram instalados em 2001, utilizando o delineamento de blocos casualizados com três repetições e parcelas de uma linha com cinco plantas. A característica avaliada foi circunferência à altura do peito (CAP) aos 30 e 84 meses da data de plantio. A eficiência da seleção precoce foi avaliada por meio da flutuação dos parâmetros genéticos e fenotípicos, índice de coincidência, correlação genética, correlação fenotípica, correlação classificatória de Spearman, resposta correlacionada, ganhos por ano e repetibilidade dos valores fenotípicos ao nível de indivíduo. Em todas as metodologias empregadas, verificou-se que a seleção precoce é eficaz, tanto na seleção de genitores quanto na seleção de árvores para clonagem.
\end{abstract}

Palavras-chave: índice de coincidência, correlação genética, resposta correlacionada, ganhos por ano. 


\section{REFERENCES}

Andrade HB, Ramalho MAP, Bueno Filho JSS, Resende MDV, Xavier A and Scolforo JRS (2006) Alternativas para atenuar a diferença de estande nos experimentos de avaliação de clones de Eucalyptus urophylla. Revista Árvore 18: 11-18.

Andrade HB, Soares AR, Ramalho MAP and David AC (1994) Avaliação de espécies e procedências de Eucalyptus L'Héritier (Myrtaceae) nas Regiões Norte e Noroeste do Estado de Minas Gerais. Revista Árvore 30: 215-299.

Bison O, Ramalho MAP, Rezende GDSP and Resende MDV (2006) Comparison between open pollinated progenies and hybrids performance in Eucalyptus grandis and Eucalyptus urophylla. Silvae Genetica 55: 92-196.

Bison O, Aguiar AM, Rezende GDSP and Ramalho MAP (2004) Inbreeding depression in Eucalyptus clones. Crop Breeding and Applied Biotechnology 4: 459-464.

Borralho NMG, Kanowski PJ and Cotterill PP (1992) Genetic control of growth of Eucalyptus globulus in Portugal. Silvae Genetica 41: 39-45.

Bouvet JM, Saya A and Vigneron PH (2009) Trends in additive, dominance and environmental effects with age for growth traits in Eucalyptus hybrid populations. Euphytica 165: 35-54.

Falconer DS and Mackay TFC (1996) Introduction to quantitative genetics. Longman, London, 463p.

Gonçalves FMA, Rezende GDSP, Bertolucci FLG and Ramalho MAP (2001) Progresso genético por meio da seleção de clones de eucalipto em plantios comerciais. Revista Árvore 25: 295 301 .

Hamblin JE and Zimmermann MJO (1986) Breeding common bean for yield in mixtures. Plant Breeding Reviews 4: 245272.

Kerr RJ, Dieters MT and Tier B (2004) Simulation of the comparative gains from four different hybrid tree breeding strategies. Canadian Journal of Forest Research 34: 209220.

Knapp SJ, Stroup WW and Ross WM (1985) Exact confidence intervals for heritability on a progeny mean basis. Crop Science 25: 192-194.
Lambeth CC (1980) Juvenile-mature correlations in Pinaceae and implications for early selection. Forest Science 26: 571-580.

Marques Júnior OG, Andrade HB, Ramalho MAP (1996) Assessment of the early selection efficiency in Eucalyptus cloeziana F. Muell, in Northwest of Minas Gerais State. Silvae Genetica 45: $359-361$.

Paula RC, Pirres IE, Borges RCG and Cruz CD (2002) Predição de ganhos genéticos em melhoramento florestal. Pesquisa Agropecuária Brasileira 37: 159-165.

Pereira AB, Marques Júnior OG, Ramalho MAP and Althoff $\mathrm{P}$ (1997) Eficiência da seleção precoce em famílias de meiosirmãos de Eucalyptus camaldulensis Dehnh, na região noroeste do Estado de Minas Gerais. Revista Cerne 3: 67-81.

Ramalho MAP, Ferreira DF and Oliveira AC (2005) Experimentação em genética e melhoramento de plantas. Editora UFLA, Lavras, 322p.

Resende MDV (2007) Software Selegen - REML/BLUP: sistema estatístico e seleção computadorizada via modelos mistos. Embrapa Floresta, Colombo, 359p.

Resende MDV and Duarte JB (2007) Precisão e controle de qualidade em experimentos de avaliação de cultivares. Pesquisa Agropecuária Tropical 37: 182-194.

Resende MDV (2002) Genética biométrica e estatística no melhoramento de plantas perenes. Embrapa Informação Tecnológica, Brasília, 975p.

Rezende GDSP, Bertolucci FLG and Ramalho MAP (1994) Eficiência da seleção precoce na recomendação de clones avaliados no Norte do Espírito Santo e Sul da Bahia. Revista Cerne 1: 45-50.

SAS Institute (2000) SAS/STAT User's guide. SAS Institute, Cary, 1028p.

Steel RGD and Torrie JH (1988) Bioestatística: princípios e procedimentos. McGraw-Hill, México, 622p.

Tolfo ALT, Paula RC, Bonine CAV, Bassa A and Valle CF (2005) Parâmetros genéticos para caracteres de crescimento, de produção e tecnológicos da madeira em clones de Eucalyptus spp. Scientia Florestalis 67: 101-110. 